\title{
Catalytic reforming of dimethyl ether in microchannels
}

\author{
Cristian Ledesma ${ }^{\mathrm{a}}$, Eduardo López ${ }^{\mathrm{a}, \mathrm{b}}$, Trifon Trifonov ${ }^{\mathrm{c}}$, Ángel Rodríguez ${ }^{\mathrm{d}}$, Jordi Llorca ${ }^{\mathrm{a}, \mathrm{c}, \mathrm{e}, *}$ \\ ${ }^{a}$ Institute of Energy Technologies, Universitat Politècnica de Catalunya, EEBE, Eduard Maristany 16, 08019 Barcelona, Spain \\ b Planta Piloto de Ingeniería Química, UNS, CONICET, Camino La Carrindanga km 7, 8000 Bahía Blanca, Argentina \\ ${ }^{\mathrm{c}}$ Barcelona Research Center in Multiscale Science and Engineering, Universitat Politècnica de Catalunya, EEBE, Eduard Maristany 16, 08019 Barcelona, Spain \\ d Department of Electronic Engineering, Universitat Politècnica de Catalunya, Campus Nord, Jordi Girona 1-3, 08034 Barcelona, Spain \\ e Department of Chemical Engineering, Universitat Politècnica de Catalunya, EEBE, Eduard Maristany 16, 08019 Barcelona, Spain
}

\section{A R T I C L E I N F O}

\section{Keywords:}

Hydrogen

Dimethyl ether

Steam reforming

Autothermal reforming

Microreactor

Micromonolith

\begin{abstract}
A B S T R A C T
The steam reforming and oxidative steam reforming of dimethyl ether (DME) were tested at 573-773 K over a $\mathrm{CuZn} / \mathrm{ZrO}_{2}$ catalyst in microreactors with three different types of channels: ceramic square channels with side lengths of 900 and $400 \mu \mathrm{m}$, and silicon microchannels of $2 \mu \mathrm{m}$ of diameter. The channels were first coated with $\mathrm{ZrOCl}_{2}$ (ceramic channels) or $\mathrm{Zr}(\mathrm{i}-\mathrm{PrO})_{4}$ (silicon microchannels) and calcined at $773 \mathrm{~K}$ for $2 \mathrm{~h}$ to obtain a homogeneous and well-adhered $\mathrm{ZrO}_{2}$ layer, as determined by SEM, and then $\mathrm{Cu}$ and $\mathrm{Zn}(\mathrm{Cu}: \mathrm{Zn}=1: 1 \mathrm{M}, 20 \mathrm{wt} \%$ total metal) were co-impregnated. Operation at highly reduced residence time $\left(10^{-3} \mathrm{~s}\right)$ while achieving hydrogen yields similar to those recorded over the ceramic channels was possible for the silicon microchannels due to the three orders of magnitude increased contact area. In addition, the amount of catalyst used for coating the silicon microchannels was two orders of magnitude lower with respect to the conventional ceramic channels. Outstanding specific hydrogen production rates of $0.9 \mathrm{~L}_{\mathrm{N}}$ of $\mathrm{H}_{2}$ per min and $\mathrm{cm}^{3}$ of reactor volume were achieved as well as stable operation for $80 \mathrm{~h}$, which demonstrates the feasibility of using on-site, on-demand hydrogen generation from DME for portable fuel cell applications.
\end{abstract}

\section{Introduction}

Dimethyl ether (DME) can be used as a high-density hydrogen carrier facilitating the operation of fuel reformers for feeding lowtemperature fuel cells in portable applications due to its low evaporation temperature and its corrosion-safe and easy handling character. The reforming of DME represents an excellent way to feed fuel cells in small environments because DME can be easily stored in liquid form at low pressure ( $\geq 0.51 \mathrm{MPa}$ bar at $298 \mathrm{~K}$ ) and then transformed into gas by a simple pressure relief valve, thus avoiding the need of investing energy for evaporation, as it occurs with other common liquids used for on-board hydrogen generation such as methanol, ethanol, gasoline or diesel $[1,2]$. In addition, DME can be obtained from almost any carbonaceous feedstock by first generating synthesis gas and then allowing synthesis gas to react over a catalyst [3]. Given the absence of $\mathrm{C}-\mathrm{C}$ bonds in DME, which can only be cleaved at high temperatures, the catalytic reforming of DME can be carried out at moderate temperatures (573-873 K). Different catalytic reforming technologies can be applied to generate hydrogen from DME (Eq. (1)), being steam reforming $(n=0)$ and oxidative steam reforming $(0<n<3)$ the most appropriate to optimize a trade-off between energy input, hydrogen yield, operation simplicity, and catalyst stability [4-7].

$\mathrm{CH}_{3} \mathrm{OCH}_{3}+(3-n) \mathrm{H}_{2} \mathrm{O}+\mathrm{n} / 2 \mathrm{O}_{2} \rightarrow(6-n) \mathrm{H}_{2}+2 \mathrm{CO}_{2}$

The catalytic reforming of DME at moderate temperature consists of two consecutive reactions; first, DME is hydrolyzed to methanol over an acid catalyst, and then methanol is subsequently transformed into a mixture of $\mathrm{H}_{2}$ and $\mathrm{CO}_{\mathrm{x}}$ over a metal function with the participation of the water gas shift reaction (WGS). Acidity of the catalyst is supplied by the support, usually $\gamma-\mathrm{Al}_{2} \mathrm{O}_{3}, \mathrm{ZrO}_{2}, \mathrm{WO}_{3} / \mathrm{ZrO}_{2}$ and zeolites such as ZSM5 [8-23], but also tungstosilicoheteropolyacids, $\mathrm{Ga}_{2} \mathrm{O}_{3} / \mathrm{TiO}_{2}$ and $\mathrm{Mo}_{2} \mathrm{C}$ [24-26], whereas the metal function is usually based on $\mathrm{Cu}$ (normally CuZn or $\mathrm{Cu} / \mathrm{CeO}_{2}$ ) [27-39] or Pd (Pd or PdZn) [40-43], although the use of other metals such as $\mathrm{Ni}, \mathrm{Pt}, \mathrm{Rh}, \mathrm{Ru}$ and $\mathrm{Au}$ [44-53] and spinel oxides such as $\mathrm{CuFe}_{2} \mathrm{O}_{4}$ have also been described in the literature [54-65]. A proper balance between the metallic and the acid functions is required to guarantee a high hydrogen yield and catalyst stability. Not only the acid amount, but also the acid strength and the type of acid-site definitely affect the steam reforming and hydrolysis activity $[10,33,37]$. The most used metal for DME steam reforming is copper (as it is the most used for methanol reforming). The interaction of $\mathrm{Cu}$ with the support and the distribution of copper species $\left(\mathrm{Cu}\right.$ metal vs. $\mathrm{Cu}^{+}$)

\footnotetext{
* Corresponding author at: Institute of Energy Technologies, Universitat Politècnica de Catalunya, EEBE, Eduard Maristany 16, 08019 Barcelona, Spain.

E-mail address: jordi.llorca@upc.edu (J. Llorca).
} 

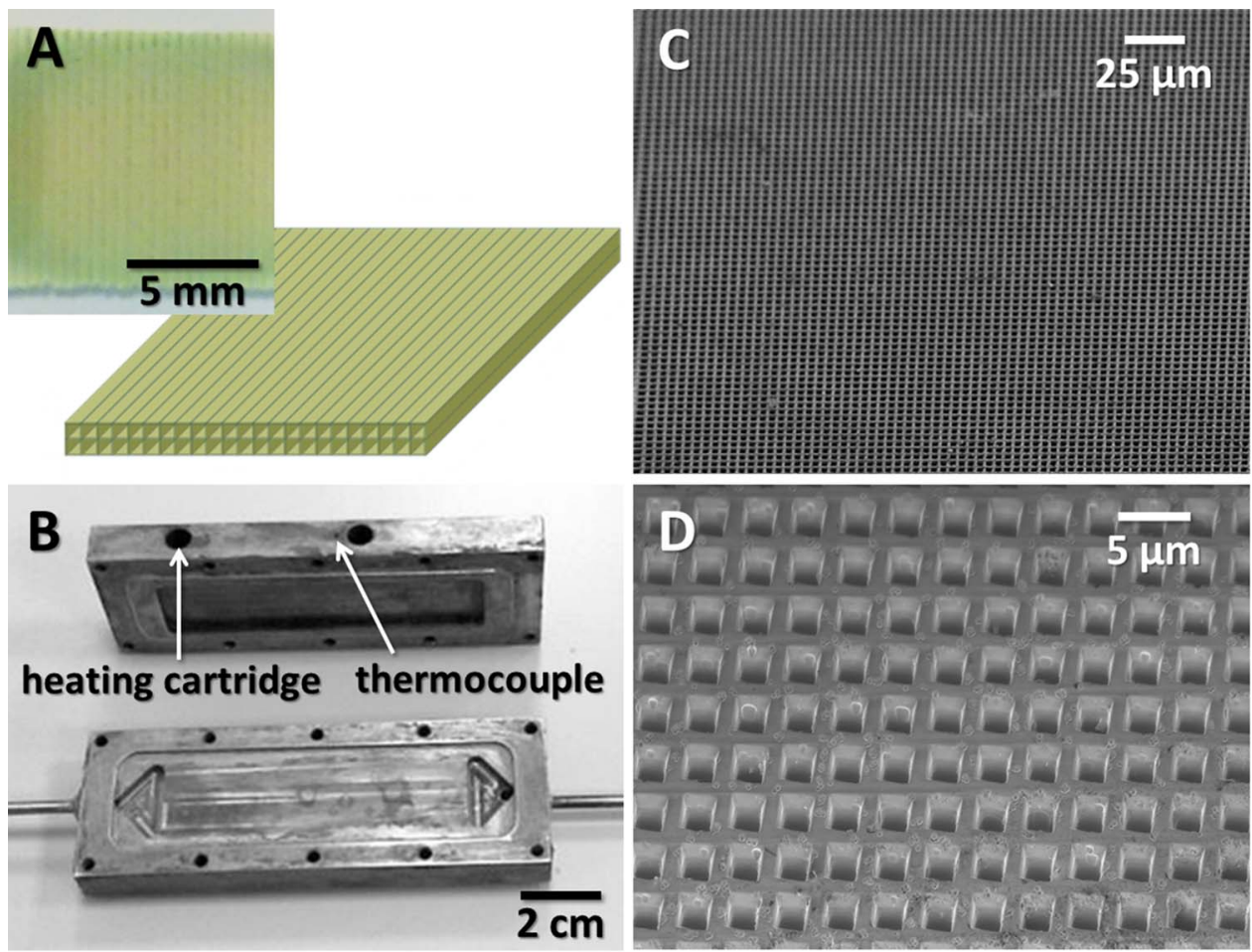

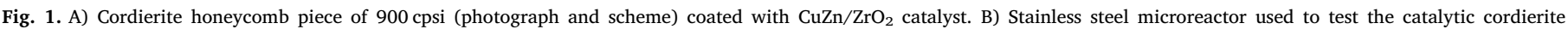
honeycomb structures. C) and D) SEM images of the microchannels of the silicon micromonoliths prepared in this work.

play a determinant role for DME reforming [30,66]. Since Cu nanoparticles tend to sinter under DME reforming conditions $\mathrm{Zn}$ is usually added to ensure a robust catalyst [16,30,35-37,46,66-68]. Also, the addition of alkaline elements and alkaline earth metal oxides in the catalyst formulation has been described to have a positive effect, either by modifying the acidity of the support and thus suppressing the formation of undesired hydrocarbons, or by changing the reducibility of the metal function of the catalyst $[18,37,53]$.

For a portable, on-demand fuel reformer, the advantage of oxidative steam reforming over steam reforming is the energy balance of the system. Whereas steam reforming is an endothermic process $\left(\Delta \mathrm{H}^{\circ} \sim 124 \mathrm{~kJ} / \mathrm{mol}\right)$, oxidative steam reforming can be carried out under autothermal conditions at the expense of hydrogen yield $[4,41,50,55,68]$. Both the catalytic steam reforming and catalytic oxidative steam reforming of DME have been widely described in the literature. Most of these studies have been addressed towards the formulation of active, selective and stable catalysts and, for practical reasons, powdered catalysts have been generally used. As an additional step in catalyst implementation for real applications a few works have been carried out over catalytic cordierite honeycombs $[21,41,42,66-72]$ as well as microreactors and foams [27,73-78]. Here we extend these studies towards process intensification in DME fuel reformers by using catalytic microstructures containing channels with smaller dimensions. In particular, we study the catalytic performance of cordierite honeycombs with channels of side lengths of 900 and $400 \mu \mathrm{m}$ and silicon microhoneycombs with microchannels of only $2 \mu \mathrm{m}$ in diameter coated with $\mathrm{CuZn} / \mathrm{ZrO}_{2}$. Lowering the dimensions of the microchannels has a strong effect on the geometric surface area exposed to reactants, which in turn has a dramatic effect on the yield of hydrogen obtained calculated on a volumetric basis $[79,80]$. Moreover, mass and heat transfer are enhanced and less amount of catalyst is required when decreasing the diameter of the microchannels, in particular for the silicon microhoneycombs.

\section{Experimental methods}

\subsection{Preparation of the catalytic structures}

\subsubsection{Conventional catalytic honeycombs}

Conventional cordierite honeycomb structures of 400 and $900 \mathrm{cpsi}$ (cells per square inch) with square channels with side lengths of 900 and $400 \mu \mathrm{m}$, respectively, were first washcoated with an aqueous solution of $\mathrm{ZrOCl}_{2} \cdot 8 \mathrm{H}_{2} \mathrm{O}$ at $353 \mathrm{~K}$ under continuous axial rotation and calcined in air at $773 \mathrm{~K}$ for $2 \mathrm{~h}$ to obtain a well-adhered layer of $\mathrm{ZrO}_{2}$ [68]. Then, $\mathrm{Cu}$ and $\mathrm{Zn}$ were incorporated by a single-step incipient wetness impregnation from an ethanolic solution of $\mathrm{Cu}\left(\mathrm{NO}_{3}\right)_{2} \cdot 3 \mathrm{H}_{2} \mathrm{O}$ and $\mathrm{Zn}\left(\mathrm{NO}_{3}\right)_{2} \cdot 6 \mathrm{H}_{2} \mathrm{O}(\mathrm{Cu}: \mathrm{Zn}=1: 1 \mathrm{M}, 20 \mathrm{wt} \%$ total metal) at room temperature. The resulting catalytic honeycombs were calcined in air at $773 \mathrm{~K}$ for $5 \mathrm{~h}$. The acidity values calculated from $\mathrm{NH}_{3}$-TPD were $0.8 \mathrm{mmol}_{\mathrm{NH} 3} / \mathrm{g}_{\text {catalyst }}$. A catalyst loss below $5 \mathrm{wt} \%$ was measured during adherence tests in ultrasounds at $40 \mathrm{kHz}$ for $30 \mathrm{~min}$. Honeycombs washcoated only with the $\mathrm{ZrO}_{2}$ support were used to conduct blank experiments.

\subsubsection{Silicon catalytic microhoneycombs}

Silicon microhoneycombs were prepared over $<100>$ n-type silicon wafers, with a resistivity of $2-6 \Omega \mathrm{cm}$. The channels were manufactured by photoassisted electrochemical etching and subsequent opening of the pores from the back side following the methodology described in [81]. Previously, the wafer surface was prestructured by lithography and etched with tetramethylammonium hydroxide (TMAH) to create a square array of inverted pyramids pointing toward the bulk of the wafer and defining the positions of channel growth. The electrochemical etching was carried out at $288 \mathrm{~K}$ at a constant anodic potential of $2 \mathrm{~V}$ in $5 \mathrm{wt} \%$ HF solution using an array of LEDs with an 880$\mathrm{nm}$ peak emission wavelength. After the electrochemical etching, the wafers were oxidized in $\mathrm{O}_{2}$ at $1373 \mathrm{~K}$ for $30 \mathrm{~min}$, the oxide layer on the backside was removed, and the remaining backside silicon was etched off in $25 \mathrm{wt} \%$ TMAH solution at $358 \mathrm{~K}$ until the pore tips were reached. The resulting structures were silicon wafers with a thickness of $0.2 \mathrm{~mm}$ 

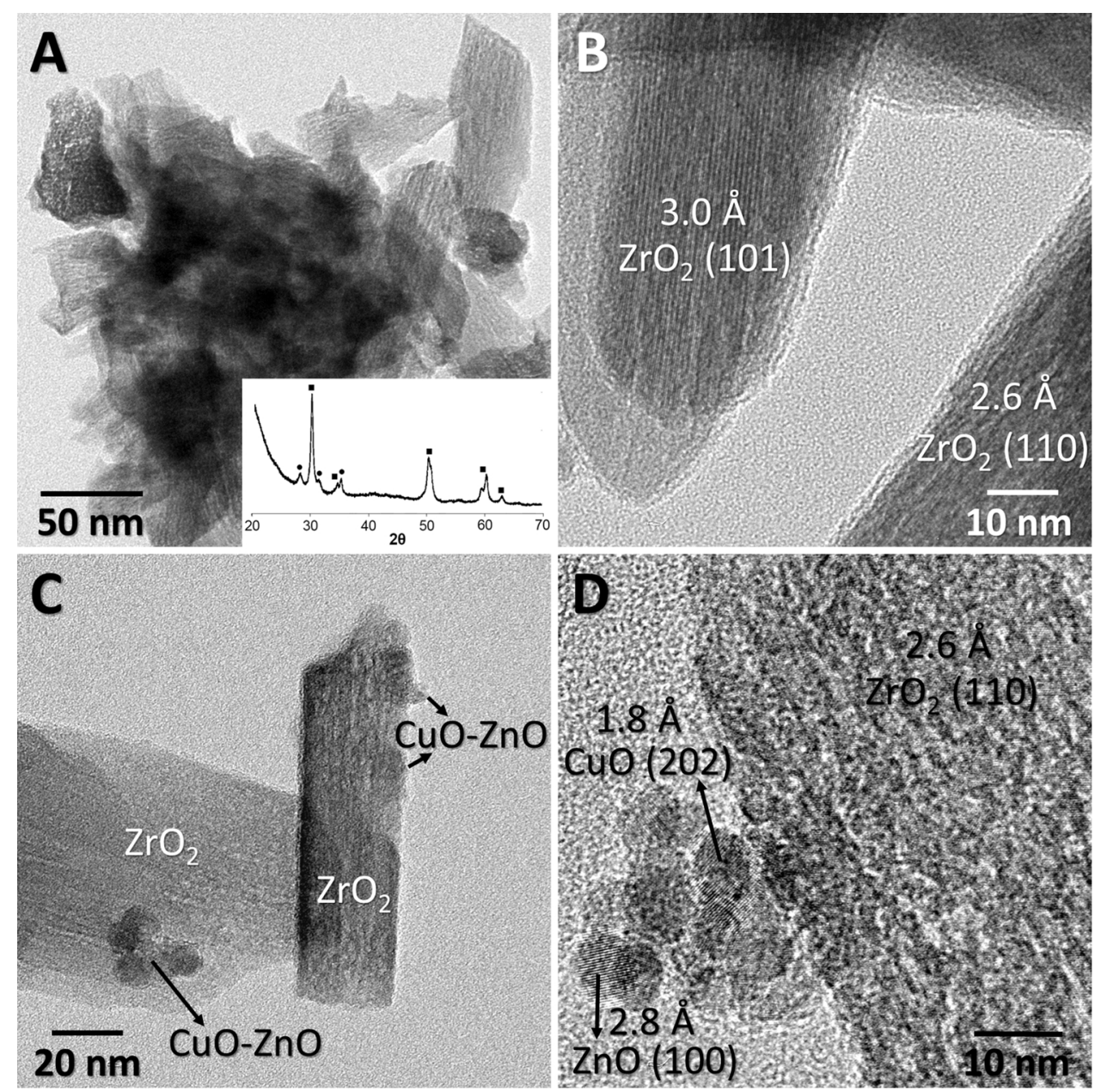

Fig. 2. A) Low-magnification TEM image and XRD pattern of the $\mathrm{ZrO}_{2}$ support particles (

tetragonal $\mathrm{ZrO}_{2},-$ monoclinic $\mathrm{ZrO}_{2}$ ). B) HRTEM image of the support particles showing the characteristic lattice fringes of $\mathrm{ZrO}_{2}$. C) and D) HRTEM images of the $\mathrm{CuZn} / \mathrm{ZrO}_{2}$ catalyst showing the occurrence of CuO and $\mathrm{ZnO}$ nanoparticles.

and with straight microchannels of $2 \mu \mathrm{m}$ in diameter arranged in a square lattice with a periodicity of $3 \mu \mathrm{m}$ (Fig. $1 \mathrm{C}$ and D), which means ca. $10^{7}$ microchannels $/ \mathrm{cm}^{2}$ and an open frontal area of $35 \%$. An insignificant pressure drop of less than 0.01 bar was measured with nitrogen flowing at $100 \mathrm{~mL} / \mathrm{min}$ and room temperature. Subsequently, the microchannels were first filled with $\mathrm{Zr}(\mathrm{i}-\mathrm{PrO})_{4}$ by applying a pressure gradient of ca. $100 \mathrm{kPa}$ and calcined at $773 \mathrm{~K}$ for $2 \mathrm{~h}$ to obtain a homogeneous and well-adhered $\mathrm{ZrO}_{2}$ layer onto the microchannels walls, and then $\mathrm{Cu}$ and $\mathrm{Zn}(\mathrm{Cu}: \mathrm{Zn}=1: 1 \mathrm{M})$ were co-impregnated following the same procedure explained above for the conventional catalytic honeycombs. This methodology is based on previous studies where catalytic layers of $\mathrm{Co} / \mathrm{ZnO}, \mathrm{RhPd} / \mathrm{CeO}_{2}$ and $\mathrm{Au} / \mathrm{TiO}_{2}$ were successfully deposited in silicon microchannels of 3-4 $\mu \mathrm{m}$ in diameter to perform the reforming of ethanol [81-83] and the preferential oxidation of carbon monoxide [84].

\subsection{Characterization techniques}

Powder X-ray diffraction (XRD) was carried out with a Bruker D8 instrument equipped with a $\mathrm{Cu}$ target at a step width of $0.02^{\circ}$ and by counting $1 \mathrm{~s}$ at each step. Scanning electron microscopy (SEM) images were recorded at $5 \mathrm{kV}$ using a Neon 40 Crossbeam Station (Zeiss) instrument equipped with a field emission source. Microstructural characterization by high-resolution transmission electron microscopy (HRTEM) was carried out at $200 \mathrm{kV}$ with a JEOL JEM-2010F electron microscope equipped with a field emission gun. X-ray photoelectron spectroscopy (XPS) was performed with a SPECS system using an $\mathrm{Al}$ Xray source $(150 \mathrm{~W})$ and a 9-channel Phoibos detector at a pressure below $10^{-6} \mathrm{~Pa}$. Quantification was carried out using Shirley baselines and Gaussian-Lorentzian lineshapes.

\subsection{Catalytic tests}

The cordierite honeycombs were cut into pieces of $20 \mathrm{~mm}$ width $\times 23 \mathrm{~mm}$ long $\times 2 \mathrm{~mm}$ height to fit into the microreactor used for the experiments (Fig. 1A). The microreactor was built in stainless steel and contained a reaction chamber equipped with two collectors for a proper gas distribution (Fig. 1B). Four heating cartridges were allocated alternately for a homogeneous temperature distribution and a thermocouple was placed at the center of the housing block (Fig. 1B). The silicon microhoneycomb wafer was cut with a laser into a disk measuring $8 \mathrm{~mm}$ in diameter and glued with epoxy into a stainless steel washer, which was sealed into a stainless steel tubular reactor and placed inside a furnace. The flowrates of DME and $\mathrm{O}_{2}$ were adjusted with mass flow controllers and $\mathrm{H}_{2} \mathrm{O}$ was dosed using a HPLC Knauer Smartline 100 pump. The effluent of the reactor was monitored on line with an Agilent 3000A micro-GC equipped with PLOT U, Stabilwax and $5 \AA$ Molsieve columns for a complete analysis. Carbon balance closure calculations were always within experimental error (5\%). The catalytic devices were first activated with a $10 \% \mathrm{H}_{2} / \mathrm{Ar}$ mixture at $573 \mathrm{~K}$ for $2 \mathrm{~h}$. Then the reaction mixture for DME steam reforming was introduced at this temperature, with a DME: $\mathrm{H}_{2} \mathrm{O}$ molar ratio of $1: 6(\mathrm{~S} / \mathrm{C}=3)$. The reaction was followed from 573 to $773 \mathrm{~K}$ at atmospheric pressure. Oxidative steam reforming was performed at $773 \mathrm{~K}$ using a $\mathrm{S} / \mathrm{C}$ ratio of 3 and a $\mathrm{O}_{2} / \mathrm{DME}$ ratio of 0.5 . DME conversion (\%) is defined as $D M E_{\text {conv }}=100 n_{D M E, c o n v} / 2 n_{D M E, \text { in, whe }} n_{D M E, c o n v}$ represents the 
moles of DME converted measured as the sum of moles of $\mathrm{CO}_{2}, \mathrm{CO}, \mathrm{CH}_{4}$ and $\mathrm{CH}_{3} \mathrm{OH}$ at the reactor outlet and $\mathrm{n}_{\mathrm{DME} \text {,in }}$ represents the moles of DME at the reactor inlet. Selectivity to species $i(\%)$ is calculated as the moles of $i$ divided by the total moles of products $\left(\mathrm{H}_{2}, \mathrm{CO}_{2}, \mathrm{CO}, \mathrm{CH}_{4}\right.$ and $\left.\mathrm{CH}_{3} \mathrm{OH}\right), \mathrm{S}_{\mathrm{i}}=100 \mathrm{n}_{\mathrm{i}} / \Sigma \mathrm{n}_{\mathrm{T}}$. Yield to species $i(\%)$ is calculated as $\mathrm{Y}_{\mathrm{i}}=\mathrm{DME}_{\text {conv }} \mathrm{S}_{\mathrm{i}} / 100$.

\section{Results and discussion}

\subsection{Characterization of the catalytic structures}

The $\mathrm{ZrO}_{2}$ support and the $\mathrm{CuZn} / \mathrm{ZrO}_{2}$ catalyst deposited on the catalytic cordierite honeycombs walls were characterized by XRD, TEM and XPS after ripping some powder off the walls. A representative, lowmagnification TEM image of the $\mathrm{ZrO}_{2}$ support particles is shown in Fig. 2A. The sample is constituted by crystalline elongated platelets of about $40-100 \mathrm{~nm}$ in length. The XRD pattern (Fig. 2A) indicates that most of the support particles are tetragonal $\mathrm{ZrO}_{2}$, with a minor contribution of monoclinic $\mathrm{ZrO}_{2}$. This is in accordance with the calcination temperature used during the synthesis [66]. A high resolution TEM image of the $\mathrm{ZrO}_{2}$ support particles is shown in Fig. 2B. The platelets show well-defined lattice fringes according to their crystalline nature, with crystallographic planes at 3.0 and $2.6 \AA$, which correspond well to the (101) and (110) planes of tetragonal $\mathrm{ZrO}_{2}$. Fig. $2 \mathrm{C}$ and $\mathrm{D}$ show representative TEM images of the $\mathrm{CuZn} / \mathrm{ZrO}_{2}$ catalyst prepared by coimpregnating the corresponding $\mathrm{Cu}$ and $\mathrm{Zn}$ nitrates over the preformed $\mathrm{ZrO}_{2}$ support particles. In addition to the elongated platelets of the $\mathrm{ZrO}_{2}$ support, the occurrence of much smaller nanoparticles of about $6-8 \mathrm{~nm}$ is clearly seen. An accurate analysis of their lattice fringes observed under HRTEM reveals that they correspond to an intimate mixture of $\mathrm{CuO}$ and $\mathrm{ZnO}$ nanoparticles. All the nanoparticles analyzed show lattice fringes corresponding to $\mathrm{CuO}$ or $\mathrm{ZnO}$. As an example, the crystallographic planes at $1.8 \AA$ of the nanoparticle shown in Fig. $2 \mathrm{D}$ are ascribed to the (202) planes of $\mathrm{CuO}$, and those at $2.8 \AA$ are ascribed to the (100) crystallographic planes of ZnO. It should be highlighted that the $\mathrm{CuO}$ and $\mathrm{ZnO}$ phases appear well mixed and in a narrow size distribution. The XPS surface analysis of the $\mathrm{CuZn} / \mathrm{ZrO}_{2}$ catalyst shows a $\mathrm{Cu} / \mathrm{Zn}$ atomic ratio of 0.87 and a $(\mathrm{Cu}+\mathrm{Zn}) / \mathrm{Zr}$ atomic ratio of 0.41 , thus indicating an excellent and homogeneous distribution of both $\mathrm{Cu}$ and $\mathrm{Zn}$, in accordance to the HRTEM results.

The characterization of the $\mathrm{CuZn} / \mathrm{ZrO}{ }_{2}$ catalyst inside the silicon microchannels was challenging given the small dimensions of the microchannels and the low catalyst loading. For a proper characterization, one of the as-prepared catalytic silicon microhoneycombs was cut and the vertical cross sections of the catalytic microchannels exposed were studied by SEM. Fig. 3 shows a representative view of the catalytic layer on the silicon microchannels. The same area is shown recorded by secondary electrons (Fig. 3A) and backscattered electrons (Fig. 3B). On top the silicon structure a well-developed layer of $\mathrm{SiO}_{2}$ of about $200 \mathrm{~nm}$ in thickness is observed (which was the result of the oxidation treatment at $1373 \mathrm{~K}$ for $30 \mathrm{~min}$ during the preparation of the silicon microchannels, as explained in Section 2.1.2) and, on top of it, a layer of the $\mathrm{ZrO}_{2}$ porous support of about $80-100 \mathrm{~nm}$ in thickness is recognized. The homogeneity and constant thickness of the $\mathrm{ZrO}_{2}$ support layer are remarkable. In addition, spherical particles are clearly visible on the $\mathrm{ZrO}_{2}$ layer; their EDX analyses show the common occurrence of $\mathrm{Cu}$ and $\mathrm{Zn}$ in all of them. Therefore, it can be assumed that similar catalyst architectures are present in the $\mathrm{CuZn} / \mathrm{ZrO}_{2}$ catalytic layers of the cordierite honeycombs and of the silicon microchannels.

\subsection{DME steam reforming and oxidative steam reforming}

The steam reforming of DME was carried out over the three types of catalytic channels at a constant S/C value of 3 at 573, 623, 673, 723 and $773 \mathrm{~K}$ and atmospheric pressure. The data reported here corresponds to steady-state values after $1 \mathrm{~h}$ of reaction; no deactivation was

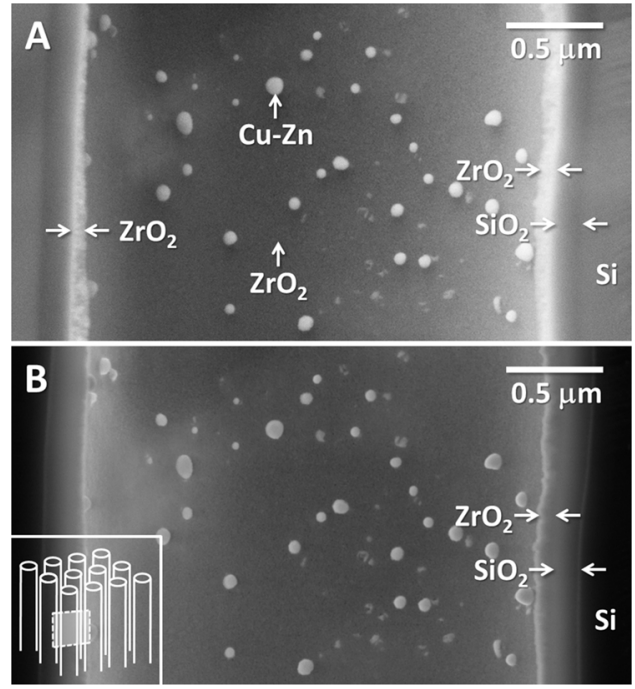

Fig. 3. SEM images recorded using secondary (A) and backscattered (B) electrons of the vertical cross section of an individual microchannel in the silicon microhoneycomb (see the scheme shown in the inset in $\mathrm{B}$ ). In addition to the Si walls of the silicon structure, layers of $\mathrm{SiO}_{2}$ and $\mathrm{ZrO}_{2}$ are clearly identified as well as $\mathrm{Cu}-\mathrm{Zn}$ nanoparticles anchored on the $\mathrm{ZrO}_{2}$ support.

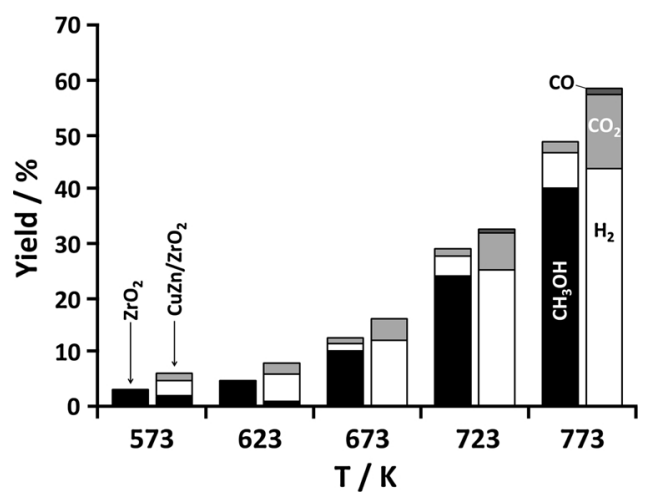

Fig. 4. Product yield obtained with a $900 \mathrm{cpsi}$ cordierite honeycomb loaded with $\mathrm{ZrO}_{2}$ and $\mathrm{CuZn} / \mathrm{ZrO}_{2}$ under DME steam reforming conditions at different temperatures. $\mathrm{S}$ / $\mathrm{C}=3, \mathrm{~T}_{\mathrm{STP}} \sim 0.5 \mathrm{~s}, \mathrm{GHSV} \sim 5 \cdot 10^{3} \mathrm{~h}^{-1}$. DME conversion corresponds to the height of the bar and product selectivity is represented by the area of each product inside each bar.

observed for any experimental condition assayed. Fig. 4 shows the DME conversion, product selectivity and product yield obtained at each temperature with the cordierite honeycomb structures of $900 \mathrm{cpsi}$ with square channels with side length of $400 \mu \mathrm{m}$ coated with the bare $\mathrm{ZrO}_{2}$ support (blank experiment) and with the $\mathrm{CuZn} / \mathrm{ZrO}_{2}$ catalyst. In both cases, the conversion of DME increased with temperature, as expected from a thermodynamic point of view taking into account the endothermic character of the process. The main product obtained over the $\mathrm{ZrO}_{2}$ support was methanol, in accordance to the first step of the reaction (the hydrolysis of dimethyl ether) and the acidic character of $\mathrm{ZrO}_{2}$. At high temperature, partial steam reforming of methanol into $\mathrm{H}_{2}$ and $\mathrm{CO}_{2}$ was observed, particularly at 723 and $773 \mathrm{~K}$. In contrast, the reaction over the $\mathrm{CuZn} / \mathrm{ZrO}_{2}$ catalyst yielded exclusively the reforming products at temperatures higher than $673 \mathrm{~K}$ (methanol was observed as an intermediate product only at lower temperature). This fact demonstrates the high activity of the CuZn phase for the steam reforming of methanol. At high temperatures, 723 and $773 \mathrm{~K}$, minor amounts of $\mathrm{CO}$ are measured in addition to the main products $\mathrm{H}_{2}$ and $\mathrm{CO}_{2}$. This is explained taking into account the water gas shift equilibrium: $\mathrm{H}_{2} \mathrm{O}+\mathrm{CO} \rightleftarrows \mathrm{H}_{2}+\mathrm{CO}_{2}$. In addition, traces of $\mathrm{CH}_{4}$ are also measured, probably as a result of the hydrogenation of $\mathrm{CO}_{\mathrm{x}}$.

Exactly the same trends were observed for the cordierite honeycomb 


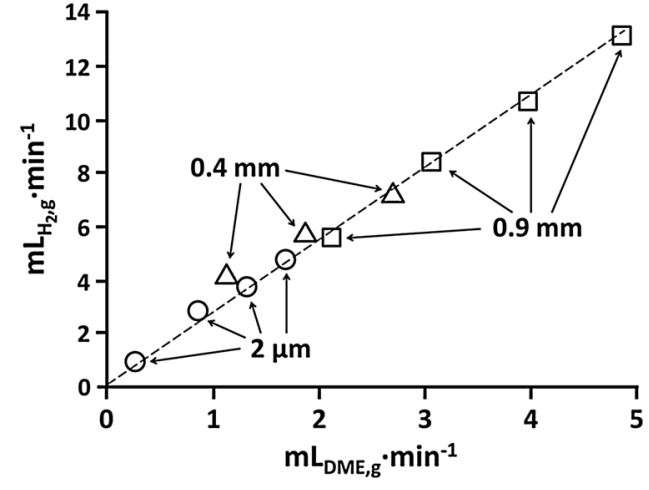

Fig. 5. Hydrogen production rates under DME steam reforming conditions using microchannels coated with $\mathrm{CuZn} / \mathrm{ZrO}_{2}$ with different diameters and DME feed flow rates. $\mathrm{T}=773 \mathrm{~K}, \mathrm{~S} / \mathrm{C}=3, \mathrm{~T}_{\mathrm{STP}} \sim 10^{-3}-1 \mathrm{~s}, \mathrm{GHSV} \sim 10^{3}-10^{5} \mathrm{~h}^{-1}$.

structures of $400 \mathrm{cpsi}$ with square channels with side length of $900 \mu \mathrm{m}$ in accordance to previous studies [68] and for the silicon micromonoliths coated with the $\mathrm{CuZn} / \mathrm{ZrO}_{2}$ catalyst. However, given the differences in their channel dimensions, the spatial conditions tested were different; in particular, the contact time $\left(\mathrm{T}_{\mathrm{STP}}\right)$ varied from $1 \mathrm{~ms}$ up to $1 \mathrm{~s}$ and the gas hourly space velocity (GHSV) varied from approximately $10^{3}$ to $10^{5} \mathrm{~h}^{-1}$. Fig. 5 shows the production of hydrogen (NmL/min) under different DME load values for the three different channel geometries recorded at $773 \mathrm{~K}$. It is remarkable that the hydrogen production values adjust well to a straight line through the origin, which means that the three channel geometries tested behave similarly in the range studied. This is a meaningful result which indicates that process intensification is plausible, even if the contact time is varied by several orders of magnitude. Therefore, an accurate comparison between the three channel geometries is not straightforward and, for that reason, a specific volumetric normalized parameter will be used here, which is defined as the amount of hydrogen generated per amount of DME in the feed (valid in the range used of $0-5 \mathrm{~mL}_{\mathrm{DME}, \mathrm{g}}$ / $\mathrm{min}$ ) for a given reactor volume: $\mathrm{mL}_{\mathrm{H} 2, \mathrm{~g}} /\left(\mathrm{mL}_{\mathrm{DME}, \mathrm{g}} \mathrm{cm}_{\text {reactor }}^{3}\right)$.

The specific volumetric production of hydrogen obtained at $773 \mathrm{~K}$ with respect to the channel diameter for the three catalytic structures is shown in Fig. 6A along with the variation of the surface area to volume ratio, $\mathrm{m}^{2} / \mathrm{m}^{3}$, and the variation of the amount of catalyst weight per surface area, $\mathrm{mg}_{\mathrm{cat}} / \mathrm{cm}^{2}$. The inverse relationship between the diameter of the microchannels and the surface area to volume ratio is a direct consequence of the geometry of the catalytic structures. The value of $4 \cdot 10^{5} \mathrm{~m}^{2} / \mathrm{m}^{3}$ corresponding to the silicon microhoneycomb with straight microchannels of $2 \mu \mathrm{m}$ in diameter represents nowadays the highest value ever reported for a structured catalytic reactor. The specific volumetric production of hydrogen with respect to the channel diameter follows a similar trend as that observed for the surface area to volume ratio. The smaller the diameter of the microchannel the higher the surface area to volume ratio and the higher the specific volumetric production of hydrogen. In particular, the ca. three order of magnitude difference between the values recorded for the silicon microchannels with respect to the conventional cordierite $400 \mathrm{cpsi}$ honeycombs merits to be highlighted. The parallel trend between the surface area to volume ratio and the specific volumetric production of hydrogen is confirmed in Fig. 6B, where a linear trend between the two parameters is evident. The specific volumetric production of hydrogen values against the geometric surface area to volume ratios adjust well to a straight line through the origin, with an approximate relationship of $\mathrm{mL}_{\mathrm{H} 2, \mathrm{~g}}$ / $\left(\mathrm{mL}\right.$ DME,g $\left.\mathrm{cm}_{\text {reactor }}^{3}\right)=0.0016 \mathrm{~m}^{2} / \mathrm{m}^{3}$. On the other hand, the amount of catalyst per surface area used in the different catalytic honeycombs is remarkably different, being the amount of catalyst present in the silicon microhoneycomb almost two orders of magnitude lower than those present in the cordierite honeycombs (Fig. 6A and B). This represents an additional advantage of using microchannels with small dimensions
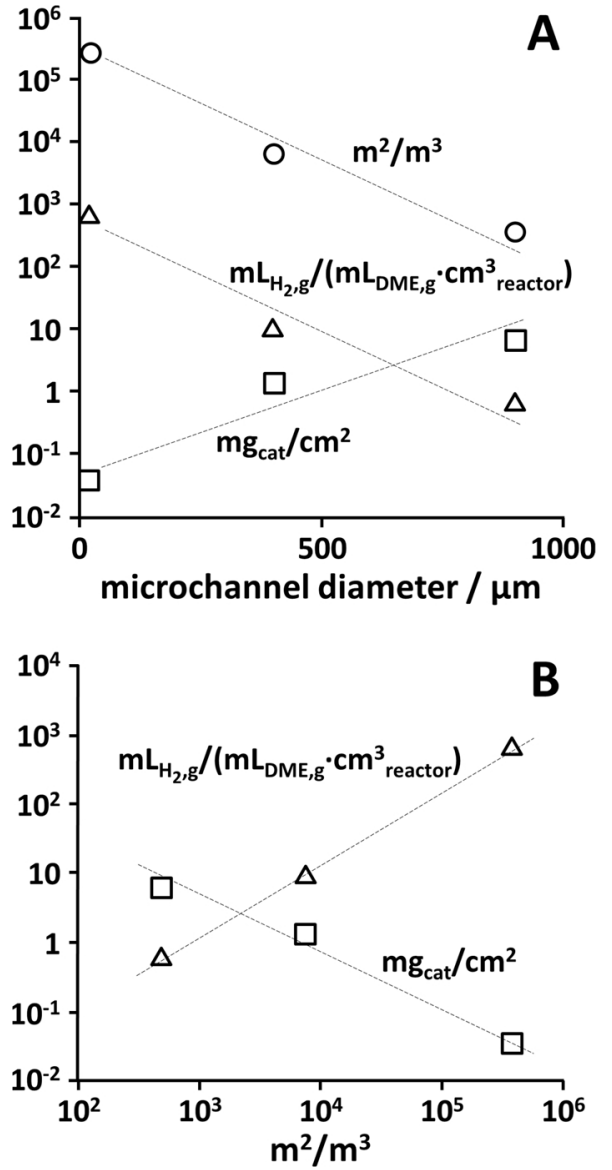

Fig. 6. Variation of surface area to volume ratio $\left(\mathrm{m}^{2} / \mathrm{m}^{3}, \mathrm{O}\right)$, catalyst loading per surface area $\left(\mathrm{mg}_{\mathrm{cat}} / \mathrm{cm}^{2}, \square\right)$ and specific volumetric production of hydrogen $\left(\mathrm{mL}_{\mathrm{H} 2, \mathrm{~g}} /\right.$ $\left.\left(\mathrm{mL}_{\mathrm{DME}, \mathrm{g}} \mathrm{cm}_{\text {reactor }}^{3}\right), \Delta\right)$ under DME steam reforming conditions using microchannels coated with $\mathrm{CuZn} / \mathrm{ZrO}_{2}$ with different diameters. $\mathrm{T}=773 \mathrm{~K}, \mathrm{~S} / \mathrm{C}=3, \mathrm{~T}_{\mathrm{STP}} \sim 10^{-3}-1 \mathrm{~s}$, GHSV $\sim 10^{3}-10^{5} \mathrm{~h}^{-1}$.

and/or catalytic structures with high surface area to volume ratio for the reforming of DME, which in addition has a beneficial economic impact. Therefore, the use of silicon microhoneycombs with regular channels of $2 \mu \mathrm{m}$ requires roughly 100 times less catalyst that the conventional cordierite $400 \mathrm{cpsi}$ honeycombs and yields 1000 times more hydrogen on a volumetric basis.

Taking into account the outstanding hydrogen production rate on a volumetric basis of the silicon microhoneycomb with respect to the cordierite honeycombs, a study of the oxidative steam reforming of DME was carried out over the silicon structure at $773 \mathrm{~K}$. The $\mathrm{S} / \mathrm{C}$ ratio was maintained constant at a value of 3 and the $\mathrm{O}_{2}$ /DME ratio was fixed at a value of 0.5 on a molar basis, which accounts for a slightly exothermic process [4,6]. As expected, the selectivity of $\mathrm{H}_{2}$ and $\mathrm{CO}$ decreased and the selectivity toward $\mathrm{CO}_{2}$ increased with respect to the DME steam reforming process due to the presence of $\mathrm{O}_{2}$ in the feed (the selectivity values recorded under DME steam reforming were $74.0 \% \mathrm{H}_{2}$, 23.3\% $\mathrm{CO}_{2}$ and $2.7 \% \mathrm{CO}$ and those recorded under DME oxidative steam reforming were $66.6 \% \mathrm{H}_{2}, 28.7 \% \mathrm{CO}_{2}$ and $4.7 \% \mathrm{CO}$ for a similar DME conversion of $\sim 60 \%$ ). The hydrogen yield also diminished, decreasing from ca. $44 \%$ for DME steam reforming conditions (Fig. 4) to $41 \%$ under DME oxidative steam reforming conditions. A stability test was performed for $80 \mathrm{~h}$ under DME oxidative steam reforming and an excellent catalytic stability was measured, as shown in Fig. 7. The inspection by SEM and TEM of the catalytic silicon microhoneycomb and the catalyst after ripping some powder off the walls after reaction did not reveal any difference with the fresh structure. Neither carbon deposition nor metal sintering was observed (Fig. 8). 


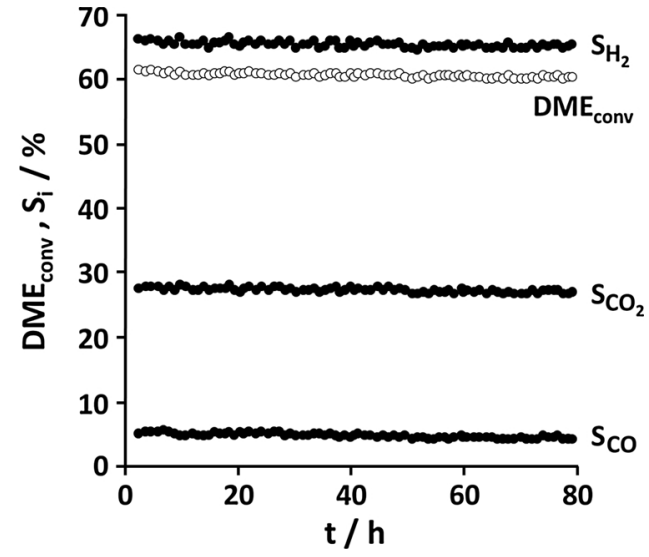

Fig. 7. Product selectivity and DME conversion during a stability test of the silicon microhoneycomb loaded with $\mathrm{CuZn} / \mathrm{ZrO}_{2}$ under DME oxidative steam reforming conditions. $\mathrm{T}=773 \mathrm{~K}, \mathrm{~S} / \mathrm{C}=3, \mathrm{O}_{2} / \mathrm{DME}=0.5, \mathrm{~T}_{\mathrm{STP}} \sim 1 \mathrm{~ms}, \mathrm{GHSV} \sim 10^{5} \mathrm{~h}^{-1}$.

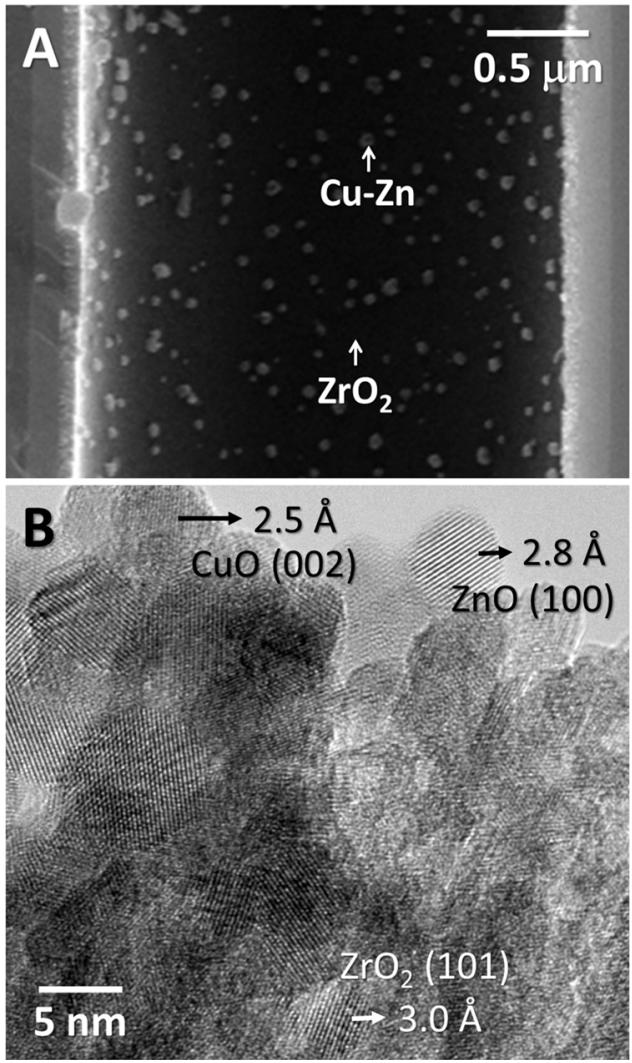

Fig. 8. SEM (A) and TEM (B) images of the catalytic silicon microhoneycomb loaded with the $\mathrm{CuZn} / \mathrm{ZrO}{ }_{2}$ catalyst after a stability test under DME oxidative steam reforming conditions for $80 \mathrm{~h}$.

\section{Conclusions}

Catalytic wall honeycombs consisting of ceramic cordierite channels with side lengths of 900 and $400 \mu \mathrm{m}$ and silicon disks containing ca. $10^{7}$ microchannels of $2 \mu \mathrm{m}$ of diameter per $\mathrm{cm}^{2}$ have been successfully coated with a homogeneous layer of $\mathrm{CuZn} / \mathrm{ZrO}_{2}$ catalyst by a two-step process. First, a support layer of $\mathrm{ZrO}_{2}$ has been adhered onto the channels walls, and then $\mathrm{Cu}$ and $\mathrm{Zn}$ have been co-impregnated. A thin catalyst layer of $80-100 \mathrm{~nm}$ in thickness has been grafted onto the silicon microchannels, which has resulted in a two order of magnitude less amount of catalyst per surface area with respect to the conventional cordierite honeycombs ( 0.03 vs. $1.5-6 \mathrm{mg}_{\text {catalyst }} / \mathrm{cm}^{2}$, respectively). Besides, given the small dimension of the silicon microchannels, the surface area to volume ratio of the silicon disks has exceeded in various orders of magnitude that of the conventional cordierite honeycombs $\left(4 \cdot 10^{5}\right.$ vs. $5 \cdot 10^{2}-8 \cdot 10^{3} \mathrm{~m}^{2} / \mathrm{m}^{3}$, respectively). As a direct consequence of both factors, the catalytic silicon microstructures have performed much better in terms of specific hydrogen production rates in the steam reforming of DME at $573-773 \mathrm{~K}\left(\mathrm{~S} / \mathrm{C}=3, \mathrm{GHSV}=10^{3}-10^{5} \mathrm{~h}^{-1}\right)$, with remarkable specific hydrogen production rates of $0.9 \mathrm{~L}_{\mathrm{N}}$ of $\mathrm{H}_{2}$ per min and $\mathrm{cm}^{3}$ of reactor volume. To improve the energy balance of the system, the oxidative steam reforming of DME has been also tested at $773 \mathrm{~K}$ with $\mathrm{O}_{2} / \mathrm{DME}=0.5$ over the silicon microchannels. It should be mentioned that the energetic cost of preheating and evaporating the surplus water used in our experiments $(\mathrm{S} / \mathrm{C}=3)$ should be considered in conjunction with the conclusions arising from the reaction performance for the final selection of the optimum operational S/C value. The implementation of catalytic silicon microchannels for on-site, on-demand hydrogen generation from DME steam reforming and oxidative steam reforming processes appears promising for portable fuel cell applications.

\section{Acknowledgments}

This work has been funded by MINECO/FEDER project ENE201563969-R. JL is a Serra Húnter Fellow and is grateful to ICREA Academia program. We are grateful to Pau Solano for technical assistance.

\section{References}

[1] D. Li, X. Li, J. Gong, Chem. Rev. 116 (2016) 11529-11653.

[2] Z. Azizi, M. Rezaeimanesh, T. Tohidian, M.R. Rahimpour, Chem. Eng. Process. 82 (2014) 150-172.

[3] J. Sun, G. Yang, Y. Yoneyama, N. Tsubaki, ACS Catal. 4 (2014) 3346-3356.

[4] K. Faungnawakij, N. Viriya-Empikul, W. Tanthapanichakoon, Int. J. Hydrogen Energy 36 (2011) 5865-5874.

[5] T.A. Semelsberger, R.L. Borup, J. Power Sources 152 (2005) 87-96.

[6] T.A. Semelsberger, R.L. Borup, J. Power Sources 155 (2006) 340-352.

[7] K. Faungnawakij, R. Kikuchi, K. Eguchi, J. Power Sources 164 (2007) 73-79.

[8] K. Takeishi, H. Suzuki, Appl. Catal. A: Gen. 260 (2004) 111-117.

[9] T. Nishiguchi, K. Oka, T. Matsumoto, H. Kanai, K. Utani, S. Imamura, Appl. Catal. A: Gen. 301 (2006) 66-74.

[10] K. Faungnawakij, Y. Tanaka, N. Shimoda, T. Fukunaga, S. Kawashima, R. Kikuchi, K. Eguchi, Appl. Catal. A: Gen. 304 (2006) 40-48.

[11] T. Kawabata, H. Matsuoka, T. Shishido, D. Li, Y. Tian, T. Sano, K. Takehira, Appl. Catal. A: Gen. 308 (2006) 82-90.

[12] K. Oka, T. Nishiguchi, H. Kanai, K. Utani, S. Imamura, Appl. Catal. A: Gen. 309 (2006) 187-191.

[13] T.A. Semelsberger, K.C. Ott, R.L. Borup, H.L. Greene, Appl. Catal. A: Gen. 309 (2006) 210-223.

[14] K. Faungnawakij, R. Kikuchi, T. Matsui, T. Fukunaga, K. Eguchi, Appl. Catal. A: Gen. 333 (2007) 114-121.

[15] A.G. Gayubo, J. Vicente, J. Ereña, L. Oar-Arteta, M.J. Azkoiti, M. Olazar, J. Bilbao, Appl. Catal. A: Gen. 483 (2014) 76-84.

[16] Z. Sun, M. Meng, L. Zhang, Y. Zha, X. Zhou, Z. Jiang, S. Zhang, Y. Huang, Int. J. Hydrogen Energy 37 (2012) 18860-18869.

[17] J. Ereña, J. Vicente, A.T. Aguayo, A.G. Gayubo, M. Olazar, J. Bilbao, Int. J. Hydrogen Energy 38 (2013) 10019-10028.

[18] J. Vicente, A.G. Gayubo, J. Ereña, A.T. Aguayo, M. Olazar, J. Bilbao, Appl. Catal. B: Environ. 130-131 (2013) 73-83.

[19] X. Long, Q. Zhang, Z.T. Liu, P. Qi, J. Lu, Z.W. Liu, Appl. Catal. B: Environ. 134-135 (2013) 381-388.

[20] D. Feng, Y. Wang, D. Wang, J. Wang, Chem. Eng. J. 146 (2009) 477-485.

[21] C. Ledesma, J. Llorca, Chem. Eng. J. 154 (2009) 281-286.

[22] J. Li, Q.J. Zhang, X. Long, P. Qi, Z.T. Liu, Z.W. Liu, Chem. Eng. J. 187 (2012) 299-305.

[23] S. Zhou, K. Ma, Y. Tian, M. Meng, T. Ding, Y. Zha, T. Zhang, X. Li, RSC Adv. 6 (2016) 52411-52420.

[24] V.V. Galvita, G.L. Semin, V.D. Belyaev, T.M. Yurieva, V.A. Sobyanin, Appl. Catal. A: Gen. 216 (2001) 85-90.

[25] T. Mathewa, Y. Yamada, A. Ueda, H. Shioyama, T. Kobayashi, C.S. Gopinath, Appl. Catal. A: Gen. 300 (2006) 58-66.

[26] F. Solymosi, R. Barthos, A. Kecskeméti, Appl. Catal. A: Gen. 350 (2008) 30-37.

[27] R. Kousar, D.H. Kim, B.Y. Yu, H.P. Ha, S.H. Kim, J.Y. Byun, Appl. Catal. A: Gen. 423-424 (2012) 176-184.

[28] S. Park, B. Choi, H. Kim, Y.J. Lee, Appl. Catal. A: Gen, 437-438 (2012) 173-183.

[29] K. Takeishi, Y. Akaike, Appl. Catal. A: Gen. 510 (2016) 20-26.

[30] X. Wang, K. Ma, L. Guo, Y. Tian, Q. Cheng, X. Bai, J. Huang, T. Ding, X. Li, Appl. Catal. A: Gen. 540 (2017) 37-46.

[31] X. Zhou, M. Meng, Z. Sun, Q. Li, Z. Jiang, Chem. Eng. J. 174 (2011) 400-407. 
[32] S.D. Badmaev, P.V. Snytnikov, Int. J. Hydrogen Energy 33 (2008) 3026-3030.

[33] X. Wang, X. Pan, R. Lin, S. Kou, W. Zou, J.X. Ma, Int. J. Hydrogen Energy 35 (2010) 4060-4068.

[34] P.V. Snytnikov, S.D. Badmaev, G.G. Volkova, D.I. Potemkin, M.M. Zyryanova, V.D. Belyaev, V.A. Sobyanin, Int. J. Hydrogen Energy 37 (2012) 16388-16396.

[35] L. Oar-Arteta, A. Remiro, J. Vicente, A.T. Aguayo, J. Bilbao, A.G. Gayubo, Fue] Process. Technol. 126 (2014) 145-154.

[36] L. Zhang, M. Meng, S. Zhou, Z. Sun, J. Zhang, Y. Xie, T. Hu, J. Power Sources 232 (2013) 286-296.

[37] J. Ereña, J. Vicente, A.T. Aguayo, M. Olazar, J. Bilbao, A.G. Gayubo, Appl. Catal. B: Environ. 142-143 (2013) 315-322.

[38] Y. Zang, X. Dong, C. Wang, Chem. Eng. J. 313 (2017) 1583-1592.

[39] S. Park, H. Kim, B. Choi, Catal. Today 164 (2011) 240-245.

[40] H. Yoshida, N. Iwasa, H. Akamatsu, M. Arai, Int. J. Hydrogen Energy 40 (2015) 5624-5627.

[41] M. Nilsson, K. Jansson, P. Jozsa, L.J. Pettersson, Appl. Catal. B: Environ. 86 (2009) $18-26$.

[42] C. Ledesma, U.S. Ozkan, J. Llorca, Appl. Catal. B: Environ. 101 (2011) 690-697.

[43] E. Ramos, L. Davin, I. Angurell, C. Ledesma, J. Llorca, ChemCatChem 7 (2015) $2179-2187$.

[44] Q. Zhang, X. Li, K. Fujimoto, K. Asami, Appl. Catal. A: Gen. 288 (2005) 169-174.

[45] N. Laosiripojana, S. Assabumrungrat, Appl. Catal. A: Gen. 320 (2007) 105-113.

[46] T. Fukunaga, N. Ryumon, S. Shimazu, Appl. Catal. A: Gen. 348 (2008) 193-200.

[47] A. Gazsi, I. Ugrai, F. Solymosi, Appl. Catal. A: Gen. 391 (2011) 360-366.

[48] Y. Yamada, T. Mathew, A. Ueda, H. Shioyama, T. Kobayashi, Appl. Surf. Sci. 252 (2006) 2593-2597.

[49] C. Herrera, M.A. Larrubia, P. Kowalik, I.S. Pieta, L.J. Alemany, Int. J. Hydrogen Energy 41 (2016) 19781-19788.

[50] S. Choi, J. Bae, J. Power Sources 307 (2016) 351-357.

[51] O. Zhang, F. Du, X. He, Z.T. Liu, Z.W. Liu, Y. Zhou, Catal. Today 146 (2009) 50-56.

[52] O. Mihai, A. Fathali, X. Auvray, L. Olsson, Appl. Catal. B: Environ. 160-161 (2014) 480-491.

[53] J. Li, Q. Zhang, Y. Zhao, P. Qi, C. Shao, React. Kinet. Mech. Catal. 122 (2017) 1193-1202.

[54] K. Faungnawakij, N. Shimoda, T. Fukunaga, R. Kikuchi, K. Eguchi, Appl. Catal. A: Gen. 341 (2008) 139-145.

[55] K. Faungnawakij, N. Viriya-Empikul, Appl. Catal. A: Gen. 382 (2010) 21-27.

[56] K. Faungnawakij, R. Kikuchi, T. Fukunaga, K. Eguchi, Catal. Today 138 (2008) $157-161$.

[57] K. Faungnawakij, Y. Tanaka, N. Shimoda, T. Fukunaga, R. Kikuchi, K. Eguchi, Appl. Catal. B: Environ. 74 (2007) 144-151.

[58] K. Eguchi, N. Shimoda, K. Faungnawakij, T. Matsui, R. Kikuchi, S. Kawashima, Appl. Catal. B: Environ. 80 (2008) 156-167.
[59] K. Faungnawakij, N. Shimoda, T. Fukunaga, R. Kikuchi, K. Eguchi, Appl. Catal. B: Environ. 92 (2009) 341-350.

[60] K. Faungnawakija, N. Shimoda, N. Viriya-Empikul, R. Kikuchi, K. Eguchi, Appl. Catal. B: Environ. 97 (2010) 21-27.

[61] L. Oar-Arteta, A. Remiro, A.T. Aguayo, J. Bilbao, A.G. Gayubo, Ind. Eng. Chem. Res. 54 (2015) 9722-9732.

[62] L. Oar-Arteta, A.T. Aguayo, A. Remiro, J. Bilbao, A.G. Gayubo, Ind. Eng. Chem. Res. 54 (2015) 11285-11294.

[63] L. Oar-Arteta, A. Remiro, F. Epron, N. Bion, A.T. Aguayo, J. Bilbao, A.G. Gayubo, Ind. Eng. Chem. Res. 55 (2016) 3546-3555.

[64] L. Oar-Arteta, A. Remiro, A.T. Aguayo, M. Olazar, J. Bilbao, A.G. Gayubo, RSC Adv. 6 (2016) 52411-52420.

[65] K. Faungnawakij, R. Kikuchi, T. Fukunaga, K. Eguchi, J. Phys. Chem. C 113 (2009) $18455-18458$.

[66] C. Ledesma, J. Llorca, J. Phys. Chem. C 115 (2011) 11624-11632.

[67] M. Nilsson, L.J. Pettersson, B. Lindström, Energy Fuel 20 (2006) 2164-2169.

[68] C. Ledesma, J. Llorca, Fuel 104 (2013) 711-716.

[69] S. Park, H. Kim, B. Choi, J. Ind. Eng. Chem. 16 (2010) 734-740.

[70] M. Nilsson, P. Jozsa, L.J. Pettersson, Appl. Catal. B: Environ. 76 (2007) 42-50.

[71] S. Park, B. Choi, B.S. Oh, Int. J. Hydrogen Energy 36 (2011) 6422-6432.

[72] S. Jung, B. Choi, S. Park, D.W. Lee, Y.B. Kim, Int. J. Hydrogen Energy 42 (2017) 13463-13476.

[73] M. Yang, Y. Men, S. Li, G. Chen, Appl. Catal. A: Gen. 433-434 (2012) 26-34.

[74] M. Yang, Y. Men, S. Li, G. Chen, Int. J. Hydrogen Energy 37 (2012) 8360-8369.

[75] C.F. Yan, W. Ye, C.Q. Guo, S.L. Huang, W.B. Li, W.M. Luo, Int. J. Hydrogen Energy 39 (2014) 18642-18649.

[76] C. Yan, H. Hai, R. Hu, C. Guo, S. Huang, W. Li, Y. Wen, Int. J. Hydrogen Energy 39 (2014) 18625-18631.

[77] C. Yan, H. Hai, C. Guo, W. Li, S. Huang, H. Chen, Int. J. Hydrogen Energy 39 (2014) 10409-10416.

[78] D.H. Kim, S.H. Kim, J.Y. Byun, Chem. Eng. J. 280 (2015) 468-474.

[79] I. Uriz, G. Arzamendi, E. López, J. Llorca, L.M. Gandía, Chem. Eng. J. 167 (2011) 603-609.

[80] A. Casanovas, M. Domínguez, C. Ledesma, E. López, J. Llorca, Catal. Today 143 (2009) 32-37.

[81] J. Llorca, A. Casanovas, T. Trifonov, A. Rodríguez, R. Alcubilla, J. Catal. 255 (2008) $228-233$.

[82] N.J. Divins, E. López, A. Rodríguez, D. Vega, J. Llorca, Chem. Eng. Process. Process Intensif. 64 (2013) 31-37.

[83] E. López, A. Irigoyen, T. Trifonov, A. Rodríguez, J. Llorca, Int. J. Hydrogen Energy 35 (2010) 3472-3479.

[84] N.J. Divins, E. López, M. Roig, T. Trifonov, A. Rodríguez, F. González de Rivera, L.I. Rodríguez, M. Seco, O. Rossell, J. Llorca, Chem. Eng. J. 167 (2011) 597-602. 